\title{
MENUJU WAJAH BARU PENGAJARAN SEJARAH
}

\author{
Ni Luh Warini \\ Guru Sejarah SMA 4 Singaraja
}

\begin{abstract}
Abstrak
Pendidikan itu penting bagi pengembangan kehidupan bangsa. Pendidikan sangat menentukan arah pembangunan bangsa. Salah satu agen penting dalam pendidikan yaitu guru. Seorang guru yang baik mestinya memiliki empat kompetensi guru yaitu kemampuan pedagogik, profesional, sosial dan individu. Kemampuan pedagogik dan profesional bisa di lihat dari pengusahaan materi, kemampuan memanfaatkan berbagai media dan sumber belajar yang ada di sekitarnya serta memiliki kemampuan dalam memilih dan melaksanakan berbagai metode pembelajaran dikelas secara maksimal. Penguasaan ketiga komponen tersebut memaksimalkan proses belajar mengajar di kelas yang ujungnya tentunya meningkatkan kualitas peserta didik. Hasil yang meningkat bisa dilihat dari kualitas dan kuantitas lulusan yang dihasilkan.
\end{abstract}

\section{Keywords:Materi,MediaSumber Belajar,Metode Pengajaran}

\begin{abstract}
Education is essential for the development of the nation. Education will determine the direction of development of the nation. One of the important agents in education is teacher. A good teacher should have four teacher competences. There are the ability pedagogical, professional, social and individual. Pedagogic and professional ability can be seen from the production of teaching materials, the ability to utilize a variety of media and learning resources in the surrounding areas as well as have the ability to select and implement a variety of teaching methods in class maximum. Mastery of these three components to maximize teaching and learning in the classroom which ends certainly improve the quality of learners. Improved results can be seen from the quality and quantity of graduates produced.
\end{abstract}

Keywords : Material, Media Learning Sources, Pedagogy Methode 


\section{PENDAHULUAN}

Peningkatan kualitas pendidikan yang baik akan membentuk karakter bangsa yang kuat. Salah satu cara yang dapat dilakukan adalah dengan pembelajaran sejarah bangsanya sehingga mereka memiliki rasa nasionalisme yang tinggi. Seperti yang dijelaskan oleh Sartono Kartodirdjo (1992: x) proses nationalbuilding for national identity yang dilakukan republik ini, menuntut rekonstruksi sejarah sebagai sejarah nasional yang akan mewujudkan kristalisasi identitas bangsa Indonesia. Rekonstruksi sejarah secara menyeluruh dan lengkap bagi warga masyarakat salah satunya dapat dilakukan di lembaga penyelenggara pendidikan yakni dengan pembelajaran sejarah secara berkelanjutan di sekolah-sekolah.

Mata pelajaran sejarah mengajarkan kepada siswa untuk memahami bagaimana bangsanya dibangun, sehingga bangsa Indonesia sampai seperti sekarang. Diperjelas lagi oleh Gottschalk (2006:3) bahwa pengajaran sejarah memang dapat dipergunakan untuk melatih warga negara yang setia karena memang kisah tanah airnya dapat menimbulkan rasa bangga pada diri kaum patriot atau jika kisah itu dapat demikian diubah dan disesuaikan sehingga nampaknya lebih mulia. Dari penjelasan itu terlihat betapa pentingnya pengajaran sejarah dalam menumbuhkan perasaan dan kesadaran bagi bangsa dalam pembangunan. Salah satu cara yang dapat dilakukan dengan cara mengenalkan sejarah lokal yang mereka miliki sehingga dari sana akan muncul rasa nasional dan cinta bangsanya mulai dari dirinya yaitu sejarah daerahnya yang kemudian berkembang menjadi bangsa secara nasional.

Tetapi kenyataan umumnya orang berpendapat bahwa mata pelajaran sejarah adalah suatu mata pelajaran yang tidak penting (mata pelajaran tambahan atau bijvak) (Moh.Ali: 2005:1). Yang diperjelas lagi dengan adanya pendapat Van der Muelen (1987:80) bahwa fungsi pendidikan sejarah agaknya tidak begitu jelas lagi. Hal itu terjadi karena di sekolah-sekolah, pembelajaran sejarah yang berperan dalam pembentukan karakter bangsa tidak sejalan dengan fungsi dan tugasnya yang besar dalam pembangunan. Pembelajaran sejarah di sekolah, harus diakui masih banyak kekurangan di sana-sini. Tidak sedikit siswa yang masih memiliki pandangan bahwa pelajaran sejarah tidak ubahnya hanya hafalan, biang kebosanan, dan gurunya ketinggalan zaman. Bahkan terkesan hanya cerita masa lampau yang tidak bermanfaat dan tidak menyenangkan penuh dengan cerita rekayasa dan kepentingan. Padahal 
menurut Robert van Daniels (1966: 3) menjelaskan "without history we have no knowledge of who we are or how we came to be, like victims of collective amnesia groping in the dark for our identity". Dalam usaha untuk meminimalisir kekurangan tersebut, berbagai usaha dilakukan salah satunya dengan mempersiapkan pendidik dalam hal ini guru sejarah yang memang benarbenar memiliki wawasan kesejarahan yang baik, sehingga sejarah memiliki nilai supaya tidak menjadi anak tiri dalam negeri yang sedang membangun (Kuntowijoyo, 2003:9).

Untuk itu menjadi guru sejarah yang baik pada zaman postmodern ini tidaklah mudah. Seorang guru sejarah setidaknya harus bisa mengembangkan empat kompetensi yang harus dikembangkan sebagaimana diisyaratkan oleh UU no 14 tahun 2005 tentang Guru dan Dosen pasal 10 menjelaskan bahwa kompetensi seorang guru itu mencakup kompetensi pedagogik, kompetensi kepribadian, kompetensi sosial dan kompetensi professional (dalam Sanjaya, 2009:19). Dari ke empat kompetensi tersebut kompetensi pedagogik dan professional adalah kompetensi yang berkaitan langsung dengan pembelajaran yang dilaksanakan oleh seorang guru. Oleh sebab itu kompetensi itu seharus selalu di update sesuai dengan kebutuhan jaman tanpa mengesampingkan kompetensi pribadi dan sosialnya sebagai seorang guru.

Terkait dengan guru sejarah dan pembelajaran sejarah seperti telah di sampaikan di atas, maka sewajarnya mengembangkan diri dalam pembelajaran supaya kesan tentang pembelajaran yang membosankan dan tidak menarik bagi siswa bisa dihikangkan perlu mengembangkan setidaknya empat hal yaitu penguatan kemampuan dalam pengetahuan atau penguasaan materi, pengembangan sumber belajar yang lebih dekat dengan lingkungan siswa, pengembangan media pembelajaran yang lebih mutakhir dan yang terakhir mengembangkan metode pengajaran sejarah yang inovatif. Dengan peningkatan keempat hal itu membelajaran sejarah yang terkesan kurang menantang dan menarik di mata siswa bisa di ubah.

\section{PEMBAHASAN}

Sejarah merupakan salah satu bidang studi yang kurang begitu diminati siswa, keberadaannya juga dianggap kurang penting dan tidak prestisius dimata siswa, orang tua maupun sekolah. Widja (1991 : 1) menegaskan bahwa pengajaran sejarah di sekolah, sering memunculkan kesan tidak menarik bahkan cenderung membosankan, karena guru sejarah hanya 
memberikan fakta-fakta sering berupa urutan tahun dan peristiwa belaka, sementara siswa merasakan bahwa pelajaran sejarah hanya mengulang halhal yang sama dari tingkat SD sampai SMA. Sanusi (1992 : 5) berkesimpulan bahwa para siswa umumnya mempelajari sejarah hanya karena akan diujikan dan semata-mata untuk memperoleh nilai yang baik. Surachmad (1987:9) menilai bahwa sering pelajaran sejarah tidak membawa siswa pada kemampuan menganalisis peristiwa dunia dan negaranya secara historis. Siswa tidak mampu pada taraf kemampuan untuk melihat dan berfikir secara historis. Pengetahuan sejarah mereka berhenti dan terbelenggu oleh sekumpulan data, faktafakta dan nama-nama orang, bahkan masih disangsikan apakah kumpulan data itu dapat dibenarkan apabila ditinjau dari sudut kegunaannya dalam kehidupan sebagai warga negara. Argumentasi di atas mengisyaratkan bahwa cara mengajar perlu mendapat perhatian dan penanganan secara baik, karena tujuan pengajaran sejarah bukan sekedar transfer of knowledge, tetapi juga transfer of value. Pendidikan sejarahbukan sekedar mengajarkan siswa menjadi cerdas, tetapi juga berakhlak mulia.

Pengajaran sejarah, selain bertujuan untuk mengembangkan keilmuan, juga mempunyai fungsi didaktis, sebagaimana dinyatakan oleh Kartodirdjo (1992:252) bahwa maksud pengajaran sejarah adalah agar generasi muda yang berikutnya dapat mengambil hikmah dan pelajaran dari nenek moyangnya. Secara eksplisit ditegaskan dalam kurikulum 2004 bahwa pengajaran sejarah mempunyai dua misi: (1) sebagai pendidikan intelektual, dan (2) sebagai pendidikan nilai, pendidikan kemanusiaan, pendidikan pembinaan moralitas, jati diri, nasionalisme dan identitas bangsa (Supardi,2006:128). Untuk mencapai misi tersebut, Soedjatmoko (1976 : 67) menyarankan agar pengajaran sejarah diselenggarakan sebagai suatu ovontuur bersama antara pengajar sejarah dan yang diajar. Dalam konteks ini, penekanan bukan pada hafalan fakta, melainkan riset bersama antara guru dan siswa menjadi utama.Kartodirdjo (1982:83) berpendapat bahawa sejarah dapat berfungsi dalam pendidikan apabila menyesuaikan dengan situai sosial dewasa ini dan jika studi sejarah terbatas pada pengetahuan faktafakta, maka akan menjadi steril dan mematikan minat terhadap sejarah. Sejalan dengan pemikiran tersebut, Widja (1992:2) menganalisis dan kepekaan terhadap masa depan.Substansi yang dapat dirumuskan dalam pengajaran sejarah adalah harus menggunakan multimedia, fleksibel, melibatkan siswa 
dalam keseluruhan pembelajaran, dan tidak hanya menekankan ingatan fakta. Untuk mencapai hal itu aspek pengembangan materi, sumber belajar, media dan metode pembelajaran sejarah wajib untuk ditingkatkan.

\section{Peningkatan Penguasaan Materi}

Perubahan kurikulum dari Kurikulum Berbasis Kompetensi ke Kurikulum Tingkat Satuan Pendidikan (KTSP) seharusnya memberikan angin segar bagi pembelajaran ilmu sosial di sekolah-sekolah. Karena pada hakikatnya KTSP menurut Peraturan Pemerintah Republik Indonesia Nomor 19 Tahun 2005 khususnya pada pasal 1 ayat 15 dinyatakan, "Kurikulum tingkat satuan pendidikan adalah kurikulum operasional yang disusun oleh dan dilaksanakan di masing-masing satuan pendidikan". Yang diperkuat oleh Mulyasa (2007 : 19) menyatakan bahwa KTSP adalah sebuah kurikulum operasional pendidikan yang disusun dan dilaksanakan di masingmasing satuan pendidikan.

Dari pengertian itu memperjelas posisi sekolah dan guru yang diberikan kesempatan untuk mengembangkan materi sesuai dengan karakter daerahnya. Ini bisa menjadi titik terang bagi pengajaran sejarah di sekolah-sekolah, materi yang dahulunya bersifat nasional bisa lebih didekatkan dengan lingkungan siswa, sehingga siswa tertarik untuk mengetahuinya. Karena pada dasarnya pengajaran sejarah memungkinan pendidik untuk mengembangkan materi sesuai dengan yang ada di sekitarnya, yakni dengan mata pelajaran muatan lokal atau di perguruan tinggi melalui mata kuliah sejarah lokal. Dengan adanya pembelajaran kontekstual dan dekat dengan lingkungan anak didik, kesan pengajaran sejarah seperti di atas dapat diminimalisir.

Bentuk-bentuk pengajaran mata pelajaran sejarah yang dekat dengan lingkungan peserta didik dapat kita mulai dengan sejarah keluarga, kemudian sejarah desa, lalu mengarah kelingkup yang lebih luas misalnya kecamatan, peristiwa yang ada di sekitar wilayah propinsi hingga akhirnya bermuara pada sejarah nasional sebagaimana tugas mata pelajaran sejarah untuk menumbuhkan rasa nasionalisme dan pembangunan karakter bangsa yang kuat (Widja, 1990).

Adalah suatu hal yang sangat ironis ketik siswa begitu paham dengan sejarah dunia, sejarah nasional namun tidak paham akan keberadaan diri dan lingkungan yang ada di sekitarnya. Menjadi sangat memprihatinkan sekali jika pendidikan kita hanya untuk mengejar kuantitas tetapi tidak memiliki kualitas jati dirinya sendiri. 
Pengembangan Media dan Sumber Belajar

Kata media berasal dari bahasa latin, yang merupakan bentuk jamak dari kata medium, yang berarti sesuatuyang terletak di tengah (antara dua kata atau kutub) atau suatu alat (Anitah, 2008:1). AECT (Association of Education and Communication Techology) (1997:201) mengatakan media sebagai segala bentuk yang digunakan untuk menyalurkan informasi. Gearlach and Ely (dalam Pupuh Fathurrohman, 2009:65) menjelaskan bahwa media apabila dipahami secara garis besar adalah manusia, materi atau kejadian yang membangun suatu kondisi yang membuat siswa mampu memperoleh pengetahuan, keterampilan atau sikap. Schraman (dalam Arief S. Sadiman, 1990:8) mengatakan media adalah teknologi pembawa informasi atau pesan instruksional.

Penggunaaan media pembelajaran di setiap proses belajar mengajar pasti memiliki manfaat guna pencapaian proses pembelajaran hal ini seperti yang dijelaskan Anitah (2008:5) yaitu: "manfaat penggunaan media ada dua yaitu ditinjau bagi pengajar dan pembelajar. Manfaat media pembelajaran bagi pengajar, yaitu memberikan pedoman arah untuk mencapai tujuan, menjelaskan struktur dan urutan pengajaran secara baik, memberikan kerangka sistematis mengajar secara baik, memudahkan kendali pengajar terhadap materi pelajaran, membantu kecermatan dan ketelitian dalam penyajian materi pelajaran, membangkitkan rasa percaya diri seorang pengajar dan meningkatkan kualitas pengajaran. Sedangkan manfaat media pembelajaran bagi pembelajar yaitu : meningkatkan motivasi belajar pembelajar, memberikan dan meningkatkan variasi belajar pembelajar, memberikan struktur materi pelajaran dan memudahkan pembelajar untuk belajar, memberikan inti informasi, pokok secara sistematik sehingga memudahkan pembelajar untuk belajar, merangsang pembelajar untuk berfikir dan menganalisis, menciptakan kondisi dan situasi belajar tanpa tekanan, dan pembelajar dapat memahami materi pelajaran dengan sistematis yang disajikan pengajar lewat media pembelajaran. Begitu penting dan bermanfaatnya media pembelajaran dalam kegiatan belajar dan pembelajaran sehingga seorang guru wajib bisa membuat mengoprasikan dan membuat media sebagai salah satu bentuk profesionalisme seorang guru. Di samping memiliki pengetahuan dan kemampuan dalam bidang pengembangan media pembelajaran guru 
juga mesti mesti mampu mengembangkan sumber belajar.

Sumber pembelajaran adalah segala sesuatu yang dapat memberikan kemudahan belajar, sehingga memperoleh kemudahan informasi, pengetahuan, pengalaman, dan keterampilan yang diperlukan (Mulyasa: 2009:177). Sumber belajar menurut Depdiknas (2004) memiliki fungsi sebagai (1) Meningkatkan produktivitas pembelajaran; (2) Memberikan kemungkinan pembelajaran yang sifatnya lebih individual; (3)Memberikan dasar yang lebih ilmiah terhadap; (4) Lebih memantapkan pembelajaran;

Memungkinkan belajar secara seketika, dan (6) Memungkinkan penyajian pembelajaran yang lebih luas. Dari pengertian tersebut seorang guru sejarah memiliki kesempatan secara maksimal untuk mengembangkan pembelajaran yang dilaksanakan dengan mengembangkan sumber belajar yang ada di sekitarnya, dengan tetap berorientasi pada materi yang akan dijelaskan.

Guru sejarah yang baik seharusnya memahami berbagai sumber belajar yang ada. Sujana (2001:77) menjelaskan bahwa sumber belajar itu dapat dibagi menjadi dua kelompok yaitu: (1) Sumber belajar yang dirancang (learning resources by design), yakni sumber belajar yang secara khusus dirancang atau dikembangkan sebagai komponen sistem instruksional untuk memberikan fasilitas belajar yang terarah dan bersifat formal. Sumber belajar yang termasuk kategori itu adalah buku teks, modul, brosur, ensklopedi, film dan video, dan (2) Sumber belajar yang dimanfaatkan (learning resources by utilization), yaitu segala sesuatu yang sudah digelar di sekitar kita, misalnya: pasar, toko, museum, tokoh masyarakat, peninggalan sejarah dan gedung lembaga. Dengan adanya pemahaman karakter materi dan juga berbagai jenis sumber belajar tersebut, guru sejarah bisa berkreasi dan berinovasi sehingga pembelajaran yang dilaksanakan tidak hanya di dalam kelas saja, namun sekali-kali bisa belajar di luar kelas melihat langsung berbagai benda peninggalan sejarah yang ada di sekitarnya.

Untuk itulah perlu ada pemahaman yang baik secara berkesinambungan oleh seorang guru sehingga bisa berkreasi dikelas. Seorang guru khususnya guru sejarah minimal bisa mengajak siswanya untuk melakukan pembelajaran sejarah di museum, bangunan kuno, Istana/ Puri Kerajaan, tugu-tugu peringatan dan yang lainnya. Ini mudah dan sangat mungkin dilaksanakan karena hampir di setiap daerah memiliki museum, bangunan kuno, peninggalan Istana Kerajaan, tugu 
peringatan yang menyimpan bendabenda dan peninggalan budaya masyarakat di sekitarnya, sehingga perlu ada kemauan dan kreatifitas dari para guru dan dosen untuk mengembangkan sumber pembelajaran tersebut.

\section{Metode Pembelajaran Inovatif}

Untuk meminimalisir beberapa permasalahan yang ada, baik yang ada pada pembelajaran sejarah itu sendiri maupun guru sejarah, perlu adanya usaha yang jelas agar proses pembelajaran sejarah lebih menarik. Penyusunan model pembelajaran sejarah harus semenarik mungkin agar siswa lebih mudah dalam menyerap materi sejarah yang di sampaikan oleh guru. Dari pengertianya sendiri, model pembelajaran adalah kesatuan yang utuh antara pendekatan, strategi, metode, teknik dan bahkan taktik pembelajaran sudah terangkai menjadi satu. Dalam pembelajaran sejarah, pengembangan model pembelajaran yang menarik sangant dibutuhkan agar mendukung suasana belajar sejarah yang kurang menarik.

Tidak menariknya pembelajaran sejarah bersumber pada anggapan keliru tentang sejarah itu sendiri. Dalam menyampaikan materi sejarah perlu ketrampilan serta model pembelajaran yang khusus dalam mengajarkan sejarah. Dalam pengembangan model pembelajaran sejarah, Widja (1989:4) mengemukakan pentingnya peranan strategi serta metode dalam kegiatan pembelajaran sejarah. Selanjutnya, dalam penyusunan startegi mengajar perlu memperhatikan beberapa faktor penentu dalam penyusunan model pembelajaran sejarah, seperti : tujuan yang hendak dicapai, keadaan dan kemampuan siswa, keadaan dan kemampuan guru, lingkungan masyarakat dan faktor lain yang bersifat khusus.

Dalam mengembangkan model pembelajaran yang menarik, sehingga tujuan pembelajaran tercapai. Widja mengemukakan beberapa strategi pokok yang umum digunakan dalam pembelajaran sejarah. Model yang dikemukakan oleh Widja ini secara umum dapat dikategorikan kedalam kelompok model pengolahan informasi dari Bruce Joyce dan kawan-kawan. Adapun penjelasan dari model yang dikembangkan Widja yaitu:

a) Model Garis Besar Kronologis

Model pembelajaran ini merupakan model pengembangan pembelajaran sejarah yang paling umum dipakai di luar negeri. Model ini mengajarkan sejarah itu sebagai suatu perkembangan atas dasar urutan tahun terjadinya suatu peristiwa sejarah. Model pembelajaran kronologi menurut S.K. Kochar (2008:399) adalah suatu tujuan 
yang penting dalam pembelajaran sejarah karena urutan peristiwa menjadi kunci pokok dalam memahami masa lampau dan masa sekarang.

Pada tiap jenjang pendidikan sekolah, baik dari tingkat dasar, maupun menengah, dan sampai ke perguruan tinggi, diberikan pelajaran sejarah yang dimulai dari awal perkembangan sampai kepada perkembangan kontemporer dari perjalanan peristiwa-peristiwa sejarah. Dalam materi sejarah di SMA, urutan kronologis materi bisa dilihat dari urutan sub-pokok bahasan seperti dimulai dari jaman pra-sejarah, hubungan India dan pengaruhnya, kemudian masuk berkembangnya Islam di Indonesia, hubungannya dengan Eropa, perang menentang kolonialisme dan imprealisme, dan seterusnya sampai dengan perkembangan kontemporer.

Pelajaran sejarah di tiap tingkatan diajarkan pada dasarnya mengikuti perkembangan kronologis yang sama. Jadi seorang siswa yang menamatkan pendidikan biasa mengalami pengulangan materi lebih dari dua kali. Alasan dari pemberian materi pelajaran sejarah yang berulang secara kronologis dalam setiap tingkat pendidikan dimaksudkan agar murid mampu memberikan gambaran peristiwa sejarah yang makin mendalam. Pemberian materi sejarah pada tiap tingkatan dimulai dari yang sifatnya elementer kemudian pada tingkatan selanjutnya lebih mendalam dan semakin mendalam. Alasan lain yang menguntungkan adalah bahwa model ini sejalan dengan esensi pokok (inti) dari sejarah yang evolusi atau proses yang berkelanjutan yang mana memang perlu menjadi perhatian murid (Widja, 1989:32).

b) Model Tematis

Model pembelajaran ini menekankan pada penanaman atau pengembangan pengertian yang mendalam untuk periode-periode tertentu dalam sejarah yang menyangkut tematema kehidupan tertentu pula. Unsur kronologi tetap tidak bisa diabaikan, tetapi yang dipentingkan ialah studi yang lebih mendalam mengenai aspek-aspek kehidupan manusia yang benar-benar menarik perhaian murid. Tema bisa diorentasikan di sekitar peranan penting tokoh-tokoh besar dalam sejarah, gejala penting dalam sejarah, sehingga nampak sebagai pembahasan besar dalam pembelajaran sejarah (Widja, 1989:33). Kegiatan belajar dapat diwujudkan melalui metode ceramah, diskusi, kegiatan proyek menyangkut tema tertentu yang biasanya bersumber dari sejarah lokal.

c) Model Garis Perkembangan Khusus

$$
\text { Pada dasarnya model }
$$
pengembangan pembelajaran sejarah ini 
sama dengan model garis besar kronologis, karena model ini menekankan pada urutan perkembangan kronologis dari peristiwa sejarah. Perbedaan model ini dibandingkan dengan model garis besar kronologis adalah terletak dalam penelusuran beberapa aspek khusus yang menarik saja dari kehidupan manusia. Ide dasar dari pengembangan model ini adalah bahwa suatu perkembangan itu hendaknya tidak diartikan sekedar sebagai peralihan dari suatu periode ke periode berikutnya, tetapi seharusnya diartikan terutama sebagai perubahan dari satu aspek kehidupan manusia. Dari berbagai peristiwa sejarah hanya diambil beberapa tema-tema yang dianggap relevan, dan menelusiri pertumbuhannya atas dasar perkembangan kronologisnya.

Jadi sebenarnya model garis pertumbuhan khusus dalam pembelajaran sejarah sebenarnya merupakan gabungan antara penekana pada unsur kronologis yang ditekankan oleh model garis besar kronologis dan penekanan pada unsur tematis yang ditekankan oleh model tematis dan minat murid sangat diperhatiakan.

d) Model Regresif

Model ini merupakan kebalikan dari model garis besar kronologis yang memulai pengajaran sejarah dari perkembangan awal terus sampai ke perkembangan sekarang (kontemporer).
Dalam model regresif menggunakan titik tolak situasi jaman sekarang untuk menelusuri balik (ke belakang) ke masa lampau yang merupakan latar belakang dari perkembangan kontemporer. Yang menjadi titik tolak dari model regresif adalah asumsi bahwa anak lebih mudah memahami serta lebih tertarik pada peristiwa yang lebih dekat dengan jamannya, dan baru kemudian beranjak ke jaman-jaman yang lebih jauh yang akan lebih mudah dipahami murid sesudah memahami masa kini.

Selain keempat model yang dijelaskan oleh Widja diatas, masih terdapat beberapa model lagi yang rasanya cukup tepat sebagai alternatif dalam pembelajaran sejarah. Misalnya adalah model pembelajaran telaah yurisprudensi, model bermain peran dan model penelitian ilmiah. Kebermanfaatan ketiga model diatas bagi pembelajaran sejarah dapat dijelaskan secara ringkas sebagai berikut :

- Model telaah yurisprudensi : model ini melatih siswa untuk peka terhadap permasalahan sosial, mengambil posisi terhadap permasalahan tersebut, serta mempertahankan sikap tersebut dengan argumentasi yang relevan dan valid. Model ini juga dapat mengajarkan siswa untuk menerima atau menghargai sikap orang lain 
terhadap suatu masalah yang mungkin bertentangan dengan sikap yang ada pada dirinya. Hal ini rasanya layak untuk digunakan dalam pembelajaran sejarah yang memang mengambil manusia dan lingkungan sosialnya pada masa lampau sebagai obyek yang dikaji. Dengan model ini maka siswa akan menemukan relevansi dan kedekatan (contextual) antara materi yang dipelajari dengan permasalahan sosial yang ada disekitarnya dengan mengambil peristiwa masa lalu sebagai analog dan pisau analisisnya.

Model bermain peran (role playing) : Model ini, pertama dibuat berdasarkan asumsi bahwa sangatlah mungkin menciptakan analogi otentik dalam suatu situasi permasalahan kehidupan nyata. Kedua, bahwa bermain peran dapat mendorong siswa mengekspresikan perasaannya. Ketiga, bahwa proses psikologi melibatkan sikap, nilai, dan keyakinan kita mengarahkan pada kesadaran melalui keterlibatan spotan yang disertai analisis. Bermain peran sebagai suatu model pembelajaran bertujuan untuk membantu siswa menemukan makna (jati diri) di dunia sosial dan memecahkan dilema dengan bantuan kelompok.
Model Penelitian Ilmiah dan Latihan Penelitian. Model latihan penelitian (research training model) sebenarnya telah dikembangkan oleh Suchman (1926) untuk mengajarkan siswa tentang proses dalam meneliti dan menjelaskan fenomena asing. Model ini melibatkan siswa dalam versiversi kecil tentang jenis-jenis prosedur yang digunakan oleh para sarjana untuk mengolah ilmu pengetahuan dan menghasilkan prinsip-prinsip. Didasarkan pada konsepsi metode ilmiah, metode ini mencoba mengajarkan siswa beberapa ketrampilan dan bahasa penelitian ilmiah. Suchman mengembangkan modelnya dengan menganalisis metode-metode yang telah digunakan oleh para peneliti kreatif, khususnya para ilmuan fisika. Saat dia mengidentifikasi unsur-unsur proses penelitian mereka, dia membentuknya menjadi model instruksional yang kemudian kita kenal dengan latihan penelitian ini (Joyce. dkk, 2009:300).Model ini sangat cocok dipergunakan dalam pembelajaran sejarah terutama bagi mahasiswa yang memang dituntut untuk mampu melakukan penelitian sejarah, ataupun siswa SMA yang memang sudah diperkenalkan materi metode penelitian sejarah sebagai 
salah satu kompetensi yang harus dikuasai. Dengan demikian diharapkan siswa tidak hanya menjadi penikmat (pembaca) dari historiografi yang ada namun mampu menuliskan peristiwa sejarah dan menghasilkan karya historiografi seminim apapun skope dan kualitasnya.

Di samping berbagai metode yang ada dan telah diterapkan di atas, metodemetode yang mutakhir yang PAIKEM

1. Jigsaw (kelompok ahli)

2. Think-Pair-Share

3. Numbered Heads Together

4. Group Investigation

1. PQ4R,

2. Guided Note Taking,

3. Snowball Drilling,

4. Concept Mapping,

1. Learning Starts With a Question

2. Plantet Question

Dengan penguasaan tiga aspek tersebut niscaya pembelajaran sejarah yang membosankan akan menjadi masa lalu, sehingga siswa lebih mengerti, tertarik dan bisa mendapatkan makna dari pembelajaran sejarah yang dilaksanakan. Seperti yang di sampaikan sejarah adalah guru bagi kehidupan (historia magistra vitae), juga perlu dikuasai oleh guru sejarah seperti dijelaskan Agus Supriyono (2009) metode pembelajaran yang baik di pakai dalam pendekatan PAIKEM dikelompokan ke dalam beberapa kelompok besar yaitu:

A. Metode-metode pembelajaran Kooperatif

5. Two Stay Two Stray, dll

B. Metode-metode Pendukung Pengembangan Pembelajaran Kooperatif

5. Giving Question and Gitting Answer, dll

C. Metode-metode Pembelajaran Aktif

3. Team Quis

4. Modeling the way

5. Silent Demonstration, dll sejarah akan menciptakan manusia yang bijaksana (history make wise) menjadi kenyataan.

\section{KESIMPULAN}

Menjadi seorang guru adalah panutan dan pelita bagi peserta didik. Oleh sebab itu, guru harus memiliki kualitas yang baik sehingga bisa memberikan tauladan dan panutan bagi peserta didiknya. Seorang guru 
harus menguasai empat kompetensi guru yang terdiri dari: kompetensi pedagogik, kompetensi professional, sosial dan personal. Kompetensi sosial dan personal menjadikan sosok guru sebagai tokoh yang digugu dan di tiru. Memiliki kemampuan pedagogic dan professional menjadikan guru pelita bagi kehidupan peserta didiknya sehingga penguasaan materi, media dan sumber belajar serta mampu mengajar dengan metode yang sesuai dengan karakter peserta didik dan juga materi yang diajarkan.

\section{Daftar Pustaka}

Daniels, Robert V. 1966. History How dan Why. New Jersey: Prentice-Hall, INC.

Berkhofer, Robert F., Jr. 1971. A Behavioral Approach to Historical Analysis. New York: A Free Press Paperback.

Gottschalk, Louis. 2006. Mengerti Sejarah (penerjemah Nugroho Notosusanto). Jakarta : UI-Press.

Joyce, Bruce. dkk. 2009. Models of Teaching; Model-Model Pengajaran. Yogyakarta : Pustaka Pelajar.

Kartodirdjo,Sartono, 1982. Pemikiran Dan

Perkembangan
Historiografi Indonesia. Jakarta : PT. Gramedia.

1992. Pendekatan Ilmu Sosial Dalam Metodologi Sejarah. Jakarta : Gramedia Pustaka Utama.

Kochar, S.K. 2008. Pembelajaran Sejarah; Teaching of History. Jakarta : Gramedia Widiasarana Indonesia.

Makmun, Abin Syamsuddin. 2003. Psikologi Pendidikan. Bandung: Rosda Karya Remaja.

Mulyasa, E. 2007. Kurikulum Tingkat Satuan Pendidikan: Sebuah Panduan Praktis. Bandung : PT Remaja Rosdakarya.

Mulyasa, E.. 2009. Menjadi Guru Profesional Menciptakan Pembelajaran Kreatif dan Menyenangkan. Bandung : Remaja Rosdakarya.

SanjayaWina. 2008. Strategi Pembelajaran; Berorientasi Standar Proses Pendidikan. Jakarta: Kencana Prenada Media Group.

Sanjaya,Wina. 2009. Strategi Pembelajaran Berorientasi Standar Proses Pendidikan. Jakarta : Kencana Prenada Media Grup.

Sanusi. 1992. Fungsi Pengajaran Sejarah Sebagai Ilmu (Makalah pada Musyawarah Kerja Nasional Sejarah XI UI-Depok). Jakarta.

Soejatmoko, 1976. Kesadaran Sejarah dalam Pembangunan dalam 
Prisma No. 7.Jakarta : LP3ES.

Sujana,Nana. dkk. 2001. Teknologi Mengajar. Bandung: Sinar Baru Algensindo.

Supriawan, Dedi dan A. Benyamin Surasega, 1990. Strategi Belajar Mengajar (Diktat Kuliah). Bandung: FPTKIKIP BandungSupardi. 2006. Pendidikan Sejarah Lokal dalam Konteks Multikulturalisme,dalam

Cakrawala Pendidikan, Pebruari 2006, th. XXV, No. 1, Yogyakarta.

Udin S. Winataputra. 2003. Strategi Belajar Mengajar. Jakarta: Pusat Penerbitan Universitas Terbuka.

Uno, Hamzah. B. 2008. Model Pembelajaran; Menciptakan Proses Belajar Mengajar yang Kreatif dan Efektif. Jakarta : Bumi Aksara.

Winarno Surachmad, 1987. Metodologi Pengajaran Nasional. Jakarta : Jenmers.

Widja,I Gde, 1991. Dasar-Dasar Pengembangan Strategi serta Metode Pengajaran sejarah. Jakarta : Depdikbud.

1992. Pendidikan Sejarah "Beban atau Kekuatan" Dalam Kurikulum di Masa Depan. (Makalah pada Musyawarah Kerja Nasional Sejarah XI UI Depok). Jakarta. 